\title{
Exploring Opportunities for Efficiency and Joint Provision of Services Using Nonappropriated Funds
}

T he U.S. Department of Defense (DoD) provides broad support services for military members and their families. While some of these services are paid for with congressionally appropriated funds, many others are covered by nonappropriated funding (NAF). However, with current defense planning calling for reductions in both the size of the force and its budget, DoD is seeking cost-saving synergies in the back-office operations of support services to facilitate maintaining those services at the current level.

A DoD task force in 2012 identified 15 areas for improvement in the use of NAF, and RAND analyzed two of them: accounting and employee benefits. RAND assessed the recommendations' costs, detailed the potential challenges, and identified how best to manage organizational changes given possible resistance to the recommendations among personnel and leadership. RAND performed cost-benefit analyses, evaluated similar consolidations of business operations in $\mathrm{DoD}$, and reviewed change management literature.

\section{NAF Accounting Options}

The services conduct their own NAF accounting functions using a variety of systems and processes that are not mutually compatible or standardized. The task force identified three courses of action (COAs) for consolidating NAF accounting options:

COA 1. Structure Update: The services would retain their independent accounting systems and systems that feed departmental and point-of-sale transactions to the general ledger, but would adopt the same standard general ledger (SGL) and migrate to cost-center structures to improve consistency of reporting.

COA 2. Common Systems: The services would select an SGL, cost-center structure, and standard core feeder and financial systems, but would maintain separate databases. This option would improve reporting, shorten staff training time, and use more web-based systems to reduce hardware costs and allow real-time data access.

COA 3. Consolidated Service Center: This option would standardize all accounting, including the SGL, costcenter structures, and core feeder and financial systems. The services would select one core financial service provider, but with no change to field personnel or program ownership.

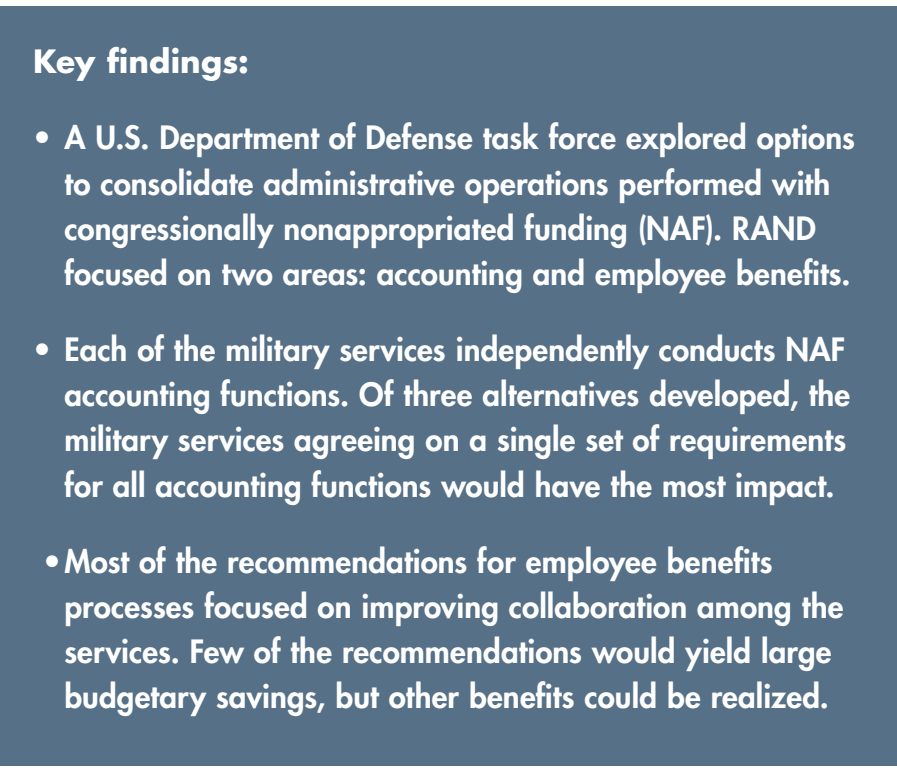

\section{Business Case}

The cost analysis for implementing COAs 2 or 3 as standalone efforts suggests significant potential savings, as shown in the table. However, implementing them as a sequence is also under consideration. If this were done, savings per COA would be significantly less because the Army's personnel savings of about $\$ 100$ million would go toward replacing its outdated accounting system. The analysis considered the costs of developing, deploying, and maintaining a new system, the estimated annual personnel savings, and the net savings over ten years after implementation.

\section{Change Management}

Change management will be challenging. Personnel are invested in the status quo and may perceive a loss of autonomy from moving to a more common system. The Office of the

\section{Learn More}

One resource found in the full report is an examination of best practices for change management. While RAND analyzed just two of the task force's 15 areas for improvement, the principles of change management could be applied to all recommendations in all areas. 


\begin{tabular}{lccc}
\cline { 2 - 4 } System Activity & Structure Update & Common Systems & Consolidated Service Center \\
\hline Development and deployment & 8.9 million & 51.5 million & 54.1 million \\
Postdeployment maintenance (annual) & 2.8 million & 4.0 million & 3.6 million \\
Personnel and reporting (annual) & -1.2 million & -18.8 million & -31.8 million \\
$\begin{array}{l}\text { Total projected net cost savings at ten years } \\
\text { after implementation }\end{array}$ & -5.4 million & -147 million & -277 million \\
\hline
\end{tabular}

Secretary of Defense (OSD) will need a well-designed communications campaign to convey the reasons for change and give all personnel a chance to engage and raise concerns. This is urgent, as the services are updating existing technologyan investment that cannot readily be recouped if a common system is chosen.

Managing change will require leadership by OSD and the NAF Accounting Working Group (established to respond to the task force recommendations) to ensure top managerial support, secure technical and financial resources, develop a detailed plan, and pursue comprehensive change.

\section{NAF Employee Benefits}

Currently, the services independently manage most employee benefits using various providers under different contracts. As a result, program offerings, enrollment and eligibility practices, and benefits received by employees vary.

The task force recommendations - too numerous to list here-are intended to reduce inaccurate benefits determinations, maximize purchasing power, and standardize NAF employee benefits across the services. They include creating summary-of-benefit forms, integrating payroll systems, and consolidating and standardizing employee benefits offerings across the services.

\section{Business Case}

The research team broke the recommendations into three categories: collaboration and standardization, implementation and coordination, and information technology and systems collaboration. The business case was based on personnel and contractor costs (but not the costs of hardware and software, because it is too early to identify the needs). Unfortunately, few of the recommendations directly reduce the cost of providing employee benefits, but there may be other benefits. First, improved communication among the services can improve the portability of employee benefits. Second, savings could also be realized as each service continued to streamline benefits administration and achieve additional synergies in contracts.

\section{Change Management}

Should the task force recommendations be implemented, several measures will be required for successful execution. Ensuring the need for change will be important to garner support and facilitate a plan because the individual services do not have a pressing need for cross-service overhead efficiencies. Increasing system similarities may improve the ease of collaboration across services and potentially reduce system liabilities and errors that cost employees time. Providing a plan for the changes, perhaps using industry standards to benchmark and create milestones for the different services, will be valuable and may help NAF benefits employees advertise the benefits provided. Managing change will require OSD leadership to ensure top managerial support and commitment and a communications campaign to engage stakeholders and the relevant action officers. RAND also recommends establishing a working group to address the task force recommendations, and plan implementation to maximize the benefits to all.

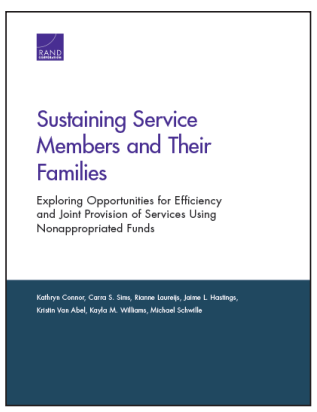

This brief describes work done in the RAND National Defense Research Institute and documented in Sustaining Service Members and Their Families: Exploring Opportunities for Efficiency and Joint Provision of Services Using Nonappropriated Funds, by Kathryn Connor, Carra S. Sims, Rianne Laureiis, Jaime L. Hastings, Kristin Van Abel, Kayla M. Williams, and Michael Schwille, RR-1175-OSD (available at www.rand.org/t/RR1175), 2016. To view this brief online, visit www.rand.org/t/RB9895. The RAND Corporation is a research organization that develops solutions to public policy challenges to help make communities throughout the world safer and more secure, healthier and more prosperous. RAND is nonprofit, nonpartisan, and committed to the public interest. RAND's publications do not necessarily reflect the opinions of its research clients and sponsors. RAND ${ }^{\circledR}$ is a registered trademark. $\odot$ RAND 2016

Limited Print and Electronic Distribution Rights: This document and trademark(s) contained herein are protected by law. This representation of RAND intellectual property is provided for noncommercial use only. Unauthorized posting of this publication online is prohibited. Permission is given to duplicate this document for personal use only, as long as it is unaltered and complete. Permission is required from RAND to reproduce, or reuse in another form, any of our research documents for commercial use. For information on reprint and linking permissions, please visit www.rand.org/pubs/permissions.html. 